\title{
Lesion healing on massive Porites spp. corals
}

\author{
R. van Woesik* \\ Department of Marine Sciences, University of the Ryukyus, Senbaru 1, Nishihara, Okinawa 903-0213, Japan
}

\begin{abstract}
Small tissue lesions 15 to $1310 \mathrm{~mm}^{2}$ were inflicted on massive Porites spp. corals living in a shallow moat $(<3 \mathrm{~m})$ in Okinawa, Japan. All but 1 lesion, affected by extreme mid-winter low tides, healed completely within 19 mo. Regeneration rates decreased exponentially over time and decreased in accordance with the lesion's surface area. The best predictive models were those using the derivatives of the exponential equations. A high perimeter to surface area ratio was a consequence of, and appeared to facilitate, regeneration. There was no significant difference in the rate of lesion regeneration between Porites lutea and Porites lobata.
\end{abstract}

KEY WORDS: Lesions - Massive Porites · Healing rates

\section{INTRODUCTION}

Massive Porites corals are prolific throughout the world's tropical oceans (Veron 1995); they are particularly common on reefs nearshore and are arguably the most important reef-building corals on the inner Great Barrier Reef (Australia) (Hopley 1982, Davies 1983). Porites colonies have long been recognised for their usefulness as temporal analogues (Buddemeier \& Kinzie 1976) and have become the focus of palaeoclimatic studies. They have been used as proxies for terrestrial runoff (Isdale 1984, Boto \& Isdale 1985), predictors of sea-surface temperature (McCullock et al. 1994), indicators of past spawning events (Gagan et al. 1994) and recorders of sea level (Woodroffe \& McLean 1990).

In the Ryukyu Islands, the island chain in southern Japan, massive Porites spp. colonies are common in shallow moats $<3 \mathrm{~m}$ deep. Disturbances to these Porites spp. colonies are frequent and range from (1) small lesions caused by gastropod and fish predation to (2) patchy die-off during low spring tides in winter to (3) sand-scouring around the base of the colonies during the typhoon season to (4) partial or whole colony

\footnotetext{
•E-mail: b984138@sci.u-ryukyu.ac.jp
}

mortality during episodes of Acanthaster planci predation (author's pers. obs.).

Studies on the regeneration of coral lesions extend back several decades (Stephenson \& Stephenson 1933, Kawaguti 1936, Fishelson 1973, Loya 1976). The capacity to regenerate appears to be species specific and dependent on lesion size, sea-surface temperature, water depth and whether the colony has been recently bleached (Lester \& Bak 1985, Meesters \& Bak 1993, Meesters et al. 1994), but appears to be independent of calcification rate (Bak \& Steward-van Es 1980). Regeneration often follows negative exponential curves, with the rate of regeneration decreasing after some time, although many studies on massive scleractinian corals show that healing is often partial and incomplete (Stephenson \& Stephenson 1933, Meesters et al. 1994).

Regeneration of Porites spp. was first reported for branching colonies by Kawaguti (1937). He indicated healing took place by the proliferation of boundary polyps. Done (1987) reported on regeneration of massive Porites following Acanthaster planci predation and suggested that living portions of injured colonies rarely encrust onto adjacent surfaces but tend to grow primarily in the direction of the original colony's radii, indicating that upward growth and subsequent fusion is most likely after infliction of wounds $\geq 30000 \mathrm{~mm}^{2}$ (which is an approximate size estimate of an extrud- 
able stomach of a sexually mature $A$. planci starfish, using Birkeland 1989).

The survival of subsurface tissue in Hawaiian Porites compressa colonies induces an unusual regeneration response, where colonies appear dead but regenerate through subsurface projections (Jokiel et al. 1993). In contrast, Atlantic Porites astreoides colonies have poor regenerative capacities, especially when lesions are $>500 \mathrm{~mm}^{2}$ (Bak \& Steward-van Es 1980), but are quite capable of regenerating smaller lesions (Meesters \& Bak 1993). Empirical measurements are not available on individual massive Porites spp. from the IndoPacific region, although rapid regeneration of massive Porites lutea, after suffering tissue damage due to sedimentation effects, can be inferred from community data in Brown et al,'s second table (1990). The present study focuses on the most common massive Porites spp. in the Indo-Pacific, P. lutea and P. lobata, and shows that $97 \%$ of tissue lesions $<1310 \mathrm{~mm}^{2}$ recover completely within 19 mo and that regeneration rates exponentially decrease with an increase in lesion size

\section{METHODS}

Field measurements. The study was undertaken in a well-flushed, clear water, inner reef moat, no more than $3 \mathrm{~m}$ deep at low spring tide, on the eastern side of Ikei Island, Okinawa, Japan (lat. 26 $23^{\circ} \mathrm{N}$, long. $\left.128^{\circ} 00^{\prime} \mathrm{E}\right)$. The experiment commenced on 22 September 1994 and ended 19 mo later. Treatments involved making 3 differently sized tissue lesions to each of 10 massive Porites spp. colonies that ranged in size from 70 to $100 \mathrm{~cm}$ in diameter. Small samples were extracted from each colony, well away from the experimental lesions, for species identification.

Lesions were inflicted in colonies between the depths of 10 and $50 \mathrm{~cm}$ below low water datum, at similar angles ranging from 15 to $40^{\circ}$ to the horizontal plane. To create the lesions, plastic plates with circular stencil holes, 100, 200 and $400 \mathrm{~mm}^{2}$ in area, were held over each colony while a jet of high pressure air was blasted over the plates. Lesions were at least $50 \mathrm{~cm}$ apart. Because the 30 subsequent lesions varied in size and shape they were categorized into 3 size classes (A $15-150$, B $151-350, C 351-1310 \mathrm{~mm}^{2}$ ). For lesion identification, stainless steel nails were set either side of each lesion along its central axis. The distance between the nail markers varied consistently in accordance with the lesion size class. Nails were set $10 \mathrm{~cm}$ apart for A size lesions, $12 \mathrm{~cm}$ apart for $\mathrm{B}$ size lesions and $15 \mathrm{~cm}$ apart for $\mathrm{C}$ size lesions.

Lesion recovery, together with algal density and abundance of sediment on each lesion, were monitored biweekly for a month, then intermittently until complete healing 19 mo later Monitoring involved measuring the lesion's longest axis and the length of its perpendicular axis to the nearest millimetre, sketching each lesion (to assess changes in lesion morphology) and measuring at least 4 other axes and their orientation depending on the lesion's shape. Care was taken not to disturb sediment or algae on the lesions. These measurements were later transcribed to $\mathrm{mm}^{2}$ grid paper from which the lesion's surface area and perimeter length were calculated.

Given the usefulness of massive Porites as sclerochronological indicators, it was hypothesized that they may also record partial mortality and healing events in their skeletons. To test this hypothesis, a core, $55 \mathrm{~mm}$ in diameter and $50 \mathrm{~mm}$ long, was extracted from 3 different Porites colonies using a pneumatic drill. The cores were taken precisely over the areas where the $C$ size lesions had healed. Cores were subsequently cut longitudinally and examined under magnification for scars.

Data analysis. Two data sets were derived from the field measurements; one recorded a change in the lesion's surface area over time, the other recorded the lesion's perimeter to surface area ratio. A general model without an asymptote was used to estimate the regeneration abilities of the corals. The changes in surface areas over time were analysed using the exponential equation

$$
\text { Lesion surface area } y=b e^{-a t}
$$

where $b$ is the intercept, e is the exponential, $a$ is the slope of the curve, and $t$ the time in days, and the equivalent equation

$$
\ln y=\ln b-a t
$$

where the dependent variable is transformed to a natural logarithm. Since there is no natural logarithm for a dependent variable of 0 , that is, where a lesion is completely healed, +1 was added to the dependent variable for calculations. It follows that the time constant $1 / a$ is the length of time it takes for the original quantity $\ln b$ to be reduced to $1 / \mathrm{e}$ of its original value. Leastsquared regressions, fitting data to Eq. (2), and slope comparisons (via analysis of covariance after testing the slopes for assumptions of parallelism, Sokal \& Rohlf 1995) were undertaken initially on data for Porites lutea and P. lobata. There were no significant differences in the slopes (Table 1); therefore, the surface area estimates were amalgamated for each size class at each observation time and used as replicates in the calculations. To calculate the rate of change in healing over time, Eq. (1) was differentiated to get

$$
\mathrm{d} y / \mathrm{d} x=-a \times b \mathrm{e}^{-d t}=-a y
$$

To test the hypothesis that a lesion's perimeter to surface area ratio had no significant association with heal- 
Table 1. Porites lutea and P. lobata. Regression analyses and slope comparisons for lesion healing on massive corals. Data were fitted to the equation $\ln y=\ln b-a$ t, where lny is natural logarithm transformation of the lesion size $+1, b$ is the intercept, $a$ is the slope of the line, and $t$ the time in days. $n$ is the number of data points, $R_{\text {adj }}$ is the percentage variance accounted for, $p_{r e q}$ is the probability of regression, and $p_{c o m p}$ is the probability of no difference between slopes. $\cdots p<0.001$, ns: not significant

\begin{tabular}{|c|c|c|c|c|c|c|}
\hline Species & Intercept (SE) & Slope (SE) & $n$ & $\mathrm{R}_{\text {adj }}^{2}$ & Preg & Pcomp \\
\hline \multicolumn{7}{|c|}{ Lesions $15-150 \mathrm{~mm}^{2}$} \\
\hline P. lutea & $3.07(0.20)$ & $-0.027(0.003)$ & 20 & 0.798 & $\cdots$ & \multirow{2}{*}{ ns } \\
\hline P. lobata & $3.54(0.41)$ & $-0.028(0.007)$ & 18 & 0.494 & $\ldots$ & \\
\hline \multicolumn{7}{|c|}{ Lesions $151-300 \mathrm{~mm}^{2}$} \\
\hline P. Iutea & $4.96(0.38)$ & $-0.019(0.003)$ & 24 & 0.601 & $\cdots$ & \multirow{2}{*}{ ns } \\
\hline P. lobata & $4.83(0.35)$ & $-0.018(0.003)$ & 23 & 0.604 & $\cdots$ & \\
\hline \multicolumn{7}{|c|}{ Lesions $301-1310 \mathrm{~mm}^{2}$} \\
\hline P. lutea & $6.32(0.32)$ & $-0.013(0.002)$ & 22 & 0.676 & $\cdots$ & \multirow{2}{*}{ ns } \\
\hline P. lobata & $5.92(0.36)$ & $-0.014(0.002)$ & 19 & 0.611 & $\cdots$ & \\
\hline
\end{tabular}

ing rate, the ratios and times until complete healing were analysed for concordance via Kendall's $\tau$ statistic (Sokal \& Rohlf 1995).

\section{RESULTS}

All lesions were covered with approximately 30\% filamentous algae after $2 \mathrm{wk}$ and with at least $60 \%$ algae and conspicuous deposits of sediment after $1 \mathrm{mo}$. Regeneration commenced with an initial 2 to $3 \mathrm{~mm}$ upward growth of the healing edge followed by lateral encroachment of soft tissue and skeleton toward the lesion's centre within the first month. The healing edge was a conspicuous pink colour in the first month, then became pale.

Macroalgae (Padina sp.) were common on the lesions in winter (December 1994)-4 mo after the lesions were inflicted. No macroalgae were present after February 1995. Lesion recovery was not deterred by filamentous or macroalgae. No evidence of grazing was seen on the lesions throughout the study. A pink fleck consistently appeared on the healing edge as it closed. The fleck turned pale 1 mo prior to complete healing. The lowest tides of the year were co-incident with the coldest yearly air temperatures (in December and January 1994/1995 the early morning low spring tides extended to -22 and $-23 \mathrm{~cm}$ respectively, while the air temperature averaged $6^{\circ} \mathrm{C}$ ). It was during this period that 3 lesions expanded ( 2 of them were at the most shallow depths, i.e. at $-11 \mathrm{~cm}$ and $-13 \mathrm{~cm}$ below datum; mean lesion depth below datum was $-29.8 \mathrm{~cm}$, with a standard deviation of 10.4 ; Table 2).

Function equations for Porites lutea and P. lobata showed slight differences between the intercepts $b$, because of initial differences in lesion size, and slight, but non significant, differences in the slopes a (Table 1). The healing functions for all 3 lesion size classes are given in Fig. 1. Lesions decreased exponentially in size through time. Using Eq. (3), the derivative of the negative exponential function, the healing rate for a lesion $y$ between 15 and $150 \mathrm{~mm}^{2}$ is $-0.029 y$ $\mathrm{mm}^{2} \mathrm{~d}^{-1}$; for a lesion $y$ between 151 and $350 \mathrm{~mm}^{2}$ the healing rate is $-0.017 y \mathrm{~mm}^{2} \mathrm{~d}^{-1}$; for a lesion $y$ between 351 and $1310 \mathrm{~mm}^{2}$ the healing rate is $-0.012 \mathrm{ymm}^{2} \mathrm{~d}^{-1}$. These functions show that the rate of healing decreases as the size of the lesion increases (Fig. 1).

Lesions progressively healed from variable shapes to ovals and circles, consequently inducing a higher perimeter to surface area ratio. Indeed, lesions with a high perimeter to surface area ratio showed significant negative correlations with healing time for lesions 15 to $150 \mathrm{~mm}^{2}$ Kendall's $\tau=-0.52, \mathrm{p}<0.001$; for lesions between 151 and $350 \mathrm{~mm}^{2}$ Kendall's $\tau=-0.48, \mathrm{p}<$ 0.001 ; for lesions between 351 and $1310 \mathrm{~mm}^{2}$ Kendall's $\tau=-0.62, p<0.001$; Table 2). In other words, lesions with a high perimeter to surface area ratio healed faster than those with a low ratio. Rarely $(6 \%$ of the time) did sequential ratios decrease over time (Table 2). The edges of some narrow, elongate lesions bridged at their narrowest point to form 2 lesions. This increased the perimeter to surface area ratio, effectively facilitating healing.

All 3 cores examined showed scars where the lesions had been. Lesions healed over accumulated debris and sediment (Fig. 2a, b). Spaces between the trabeculae and synapticulae were conspicuously large directly above the damaged surface, giving a porous appearance (Fig. 2c).

\section{DISCUSSION}

Massive Porites spp. generally grow laterally by extratentacular budding of corallites that are no larger than $1.5 \mathrm{~mm}$, and grow vertically by periodic and 

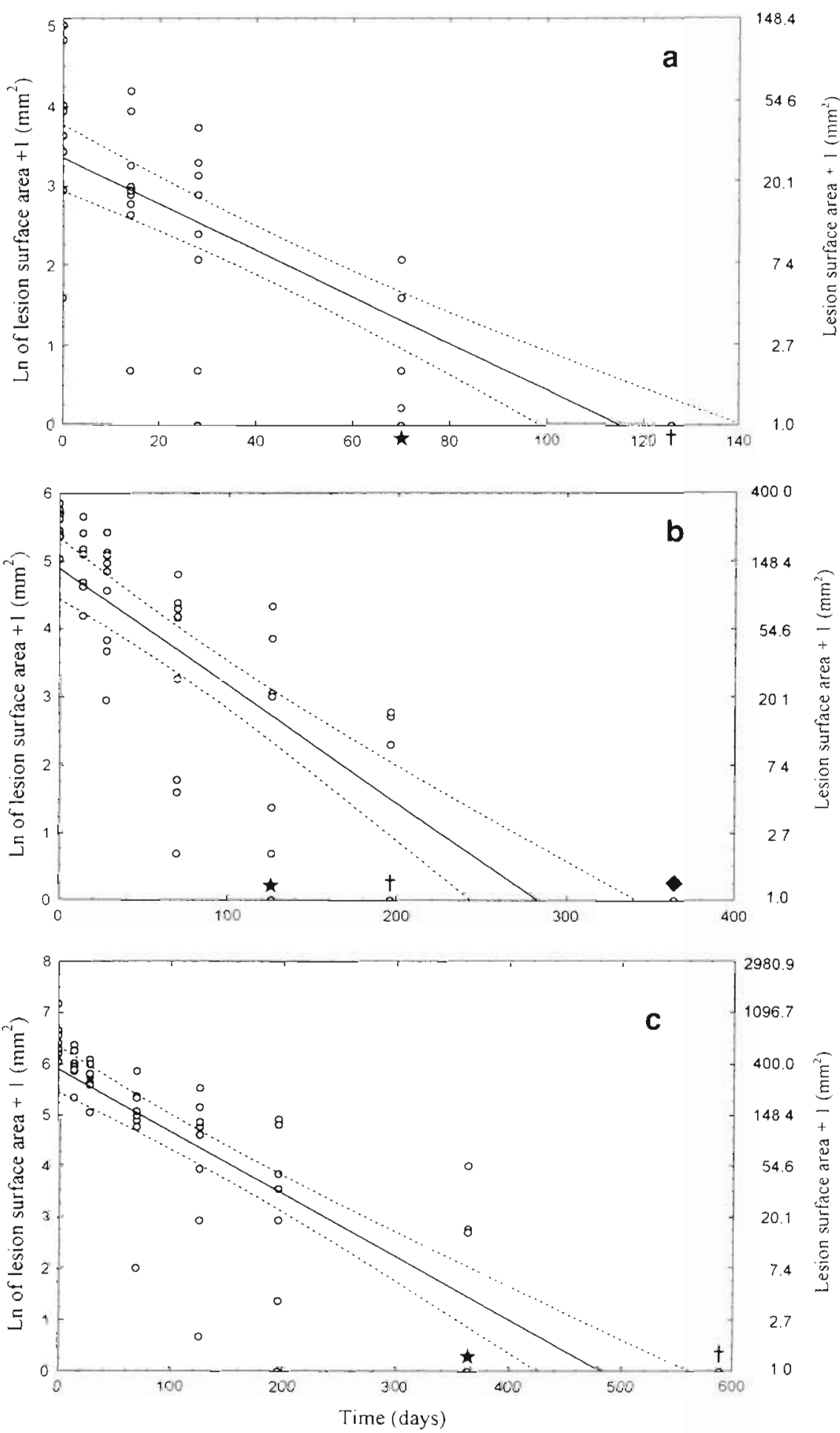

Fig. 1. Regeneration of lesions on massive Porites spp. using the exponential equation $y=b e^{-a t}$ and its equivalent $\ln y=\ln b-a t_{i}$ fitted regressions and $95 \%$ confidence limits (dashed lines) are drawn on each graph. (a) (Size A) Lesion size $y=3.36-0.029 x$ days (SE for $b$ is 0.21 , SE for $a$ is $0.003, R_{\text {ad }}^{2}=0.641, p<0.001$ ). Note overlap of $2(\star)$ and $6(\dagger)$ data points at 0 on the left $y$-axis. (b) (Size B) Lesion size $y=4.89-0.017 \times$ days ( $S E$ for $b$ is 0.23 , SE for $a$ is $0.002, R^{2}$ ad $=0.625, p<0.001$ ). Note instances of overlap of 3 data points each $(\star,+, *)$ at 0 on the left $y$-axis. (c) (Size C) Lesion size $y=5.91-0.012 \times$ days (SE for $b$ is 0.22 , SE for $a$ is $\left.0.001, R_{a d i}^{2}=0.690, p<0.001\right)$. Note overlap of $4(\star)$ and $3(t)$ data points at 0 on the left $y$-axis. Lesion $A$ from Colony 4 and lesion $C$ from Colony 9 were removed from the model because of their considerable expansion in winter; these lesions were at the most shallow depths, i.e. at $-13 \mathrm{~cm}$ and $-11 \mathrm{~cm}$ low water datum, respectively (Table 2). The time constants $1 / a$ for (a), (b), and (c) are 34,59 and $83 \mathrm{~d}$, respectively 
Table 2. Porites lobata, P. lutea and P. solida. Ratio of lesion perimeter to surface area on massive corals, where H indicates completely healed, and $\mathrm{R}$ indicates the lesion was re-classified into a smaller size class at the first observation. Depth of lesion below low water datum (LWD, cm) is given. nc: data no longer collected

\begin{tabular}{|c|c|c|c|c|c|c|c|c|c|c|}
\hline Date & $\begin{array}{l}\text { Colony } 1 \\
\text { P. lobata }\end{array}$ & $\begin{array}{l}\text { Colony } 2 \\
\text { P. lobata }\end{array}$ & $\begin{array}{l}\text { Colony } 3 \\
\text { P. solida }\end{array}$ & $\begin{array}{c}\text { Colony } 4 \\
\text { P. lutea }\end{array}$ & $\begin{array}{l}\text { Colony } 5 \\
\text { P. lobata }\end{array}$ & $\begin{array}{c}\text { Colony } 6 \\
\text { P. lutea }\end{array}$ & $\begin{array}{c}\text { Colony } 7 \\
\text { P. Iutea }\end{array}$ & $\begin{array}{c}\text { Colony } 8 \\
\text { P. lutea }\end{array}$ & $\begin{array}{c}\text { Colony } 9 \\
P . \text { lutea }\end{array}$ & $\begin{array}{l}\text { Colony } 10 \\
\text { P. lobata }\end{array}$ \\
\hline \multicolumn{11}{|c|}{ A size lesions $\left(15\right.$ to $\left.150 \mathrm{~mm}^{2}\right)$} \\
\hline Depth below LWD & -20 & -34 & -29 & -13 & -25 & -37 & -47 & -28 & -10 & -46 \\
\hline Sep 1994 & 0.36 & 2.25 & 0.54 & 0.48 & 0.34 & 0.73 & 0.65 & 0.65 & 1.33 & 0.59 \\
\hline Oct 1994 & 0.53 & 3.14 & 0.84 & 0.65 & 0.58 & 1.08 & 0.95 & 1.24 & 1.26 & 1.08 \\
\hline Nov 1994 & 0.81 & $\mathrm{H}$ & 0.95 & 0.85 & 0.71 & 1.5 & 1.4 & 3.14 & 1.50 & 1.12 \\
\hline Dec 1994 & 1.5 & & $\mathrm{H}$ & 1.27 & 2.07 & 3.14 & 2.5 & 4.00 & $\mathrm{H}$ & 2.63 \\
\hline Feb 1995 & $\mathrm{H}$ & & & $0.76^{\mathrm{a}}$ & $\mathrm{H}$ & $\mathrm{H}$ & $\mathrm{H}$ & $\mathrm{H}$ & & $\mathrm{H}$ \\
\hline Apr 1995 & & & & 1.23 & & & & & & \\
\hline Sep 1995 & & & & $\mathrm{H}$ & & & & & & \\
\hline \multicolumn{11}{|c|}{ B size lesions (151 to $300 \mathrm{~mm}^{2}$ ) } \\
\hline Depth below LWD & -25 & -45 & -32 & -18 & -30 & -35 & -40 & -25 & & -42 \\
\hline Sep 1994 & 0.33 & 0.31 & 0.28 & 0.25 & 0.27 & 0.23 & 0.21 & 0.47 & $\mathrm{R}$ & 0.28 \\
\hline Oct 1994 & 0.37 & $0.45^{b}$ & 0.35 & 0.33 & 0.29 & 0.31 & 0.22 & 0.72 & & 0.45 \\
\hline Nov 1994 & 0.33 & 1.32 & 0.38 & 0.32 & 0.30 & 0.40 & 0.24 & 1.28 & & 0.75 \\
\hline Dec 1994 & 0.44 & $2.23^{\mathrm{b}}$ & 0.51 & 0.36 & 0.36 & 0.76 & 0.52 & 3.14 & & 3.38 \\
\hline Feb 1995 & 1.25 & $\mathrm{H}$ & 0.92 & 0.48 & 0.46 & 3.00 & 3.14 & $\mathrm{H}$ & & $\mathrm{H}$ \\
\hline Apr 1995 & 2.11 & & 1.07 & 1.00 & $\mathrm{H}$ & $\mathrm{H}$ & $\mathrm{H}$ & & & \\
\hline Sep 1995 & $\mathrm{H}$ & & $\mathrm{H}$ & $\mathrm{H}$ & & & & & & \\
\hline \multicolumn{11}{|c|}{ C size lesions (301 to $1310 \mathrm{~mm}^{2}$ ) } \\
\hline Depth below LWD & -34 & -27 & -26 & -30 & -32 & -38 & -32 & & -11 & -48 \\
\hline Sep 1994 & 0.22 & 0.18 & 0.19 & 0.17 & 0.14 & 0.16 & 0.20 & $\mathrm{R}$ & 0.25 & 0.17 \\
\hline Oct 1994 & 0.33 & 0.22 & 0.29 & 0.19 & 0.23 & 0.17 & 0.23 & & 0.32 & 0.23 \\
\hline Nov 1994 & 0.39 & 0.25 & 0.25 & 0.19 & 0.27 & 0.23 & 0.24 & & $0.27^{a}$ & 0.24 \\
\hline Dec 1994 & $1.69^{\mathrm{b}}$ & 0.28 & 0.37 & 0.21 & 0.90 & 0.39 & 0.31 & & 0.72 & 0.34 \\
\hline Feb 1995 & 3.14 & 0.32 & 1.17 & 0.25 & $0.50^{\mathrm{a}}$ & 0.38 & 0.42 & & $\mathrm{nc}$ & 0.65 \\
\hline Apr 1995 & $\mathrm{H}$ & 0.43 & 2.00 & 0.38 & 0.61 & 0.39 & 0.82 & & & 1.47 \\
\hline Sep 1995 & & 0.43 & $\mathrm{H}$ & 1.33 & $\mathrm{H}$ & 1.5 & $\mathrm{H}$ & & & $\mathrm{H}$ \\
\hline Apr 1996 & & $\mathrm{H}$ & & $\mathrm{H}$ & & $\mathrm{H}$ & & & & \\
\hline $\begin{array}{l}{ }^{a} \text { Ratio is less than p } \\
{ }^{b} \text { Lesion bridged at } c\end{array}$ & $\begin{array}{l}\text { revious rat } \\
\text { centre and }\end{array}$ & formed 2 & esions & & & & & & & \\
\hline
\end{tabular}

abrupt uplift of the lower margin of the tissue layer, with calcification concentrated at the surface (Barnes \& Lough 1993). Similarly, this study showed that a lesion regenerates firstly by upward extension of the surrounding polyps, and secondly by extratentacular budding and lateral encroachment over the dead area.

The presence of filamentous algae on the lesions did not deter regeneration as long as there was an active regenerating edge. These findings are in agreement with Bak \& Stewart-van Es (1980) and Meesters \& Bak (1993), but I extend the generalisation that healing of lesions is not hindered by some filamentous and macroalgae (e.g. Padina sp.) and a light sediment loading (Barnard et al. 1974, Brown et al. 1991, Meesters et al. 1992). Lesion scars were evident in the core samples and clearly the trabeculae structures over the healed lesions were more porous than in other parts of the colony. Indeed, their existence may help clarify the extent of historical damage to Indo-Pacific Porites spp. through sclerochronological investigations (Cameron \& Endean 1985, Done 1987, Endean et al. 1988, Keesing et al. 1992) and refine predictive models on the occurrence of small lesions on Porites astreoides, for which laudable sclerochronological studies have been carried out (Ruesink 1997).

Some previous studies reported no linear relationship between colony size and regeneration capacity (Bak \& Stewart-van Es 1980). Meesters et al. (1994) suggested that healing rates of Montastrea annularis depended on the length of the lesion perimeter, but not on the size of the lesion or size of the colony. Oren et al. (1997) showed that the perimeter length of lesions on Favia favus influenced recovery rates in the first month of regeneration, but in months following recovery was influenced more by the lesion's surface area, and the surface area to perimeter ratio. Regeneration does however appear to be dependent on the amount of tissue bordering the lesion, since Meesters et al. (1996) 

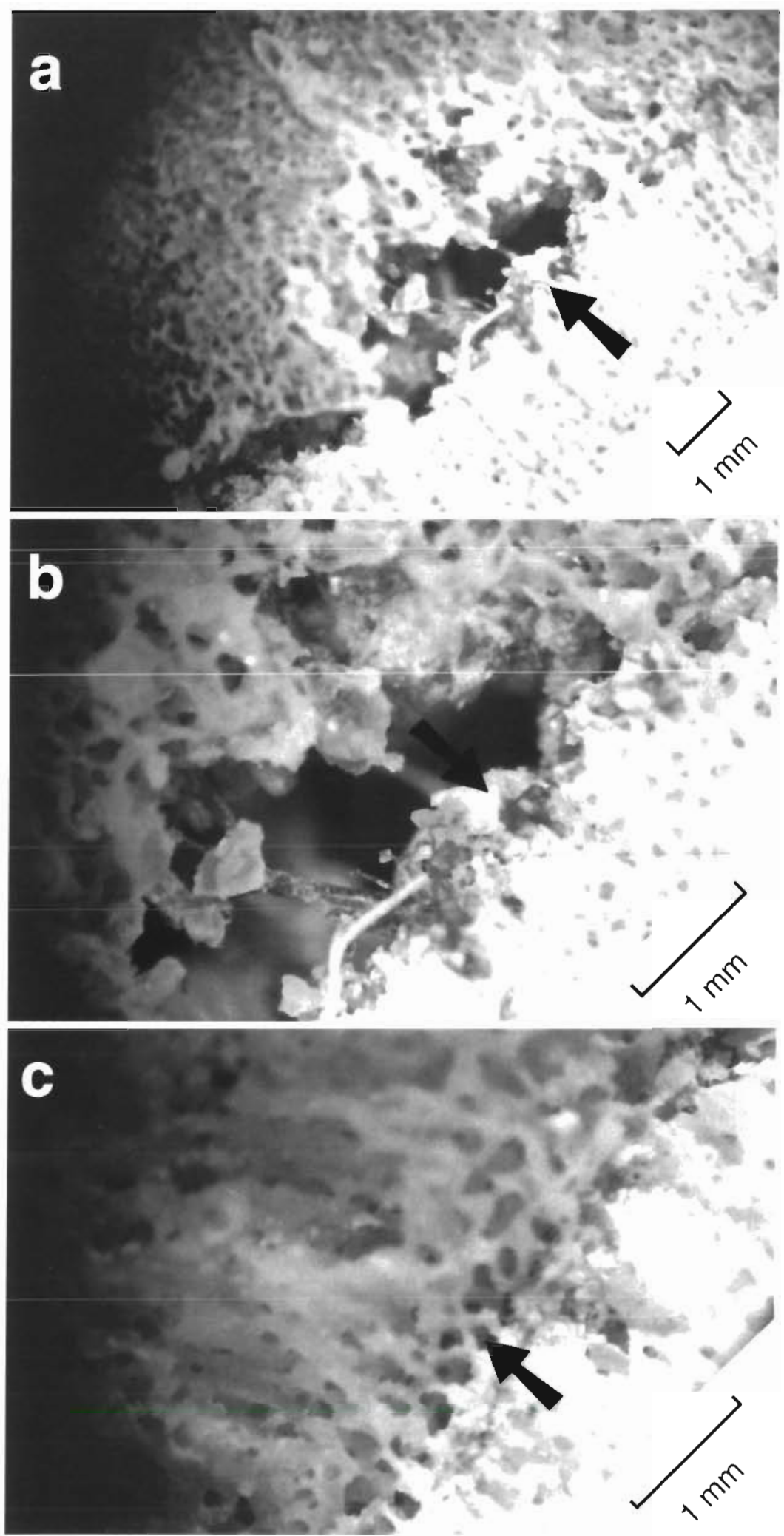

Fig. 2. Poritns lutea and Porites lobata. Cross-sections of coral colonies showing lesion scars from C size lesions. The top left of each photo is near the nuter edge of the colony. (a) Lesion scar from Colony 7, P. lutea. Arrow points to the underside of the scar (b) Niagnification of srar in (a). Arrow points to sediment particles retained on the lesion. (c) Lesion scar from Colony $10, P$. lobata. Arrow points to the porous structure between trabeculae (vertical) and synapticulae (horizontal) directly above the healed lesion 
showed small colonies with lesions suffered high mortality. The findings of the present study corroborate the idea that the length of the lesion perimeter influences the healing process, as a high perimeter to surface area ratio greatly facilitates healing, and add that regeneration rates are largely dependent on the size of the lesions.

Studies on the massive Atlantic scleractinian corals Agaricia agaricites and Montastrea annularis indicate that lesions stop regenerating simultaneously and independently of lesion size (Bak et al. 1977, Bak \& Steward-van Es 1980). Such a response was interpreted as a termination of the energy source that fueled the healing process (Bak \& Steward-van Es 1980). The present study on massive Indo-Pacific Porites spp. showed that once healing begins on lesions $<1310 \mathrm{~mm}^{2}$ it progresses until closure. However, this study also showed that regeneration rates decreased with increasing lesion size. Since the response appears to be gradual, it is presumably not a chemical on/off mechanism (Thompson 1917).

A metabolic diffusion gradient and/or active pumping (Taylor 1977, Gladfelter 1983) allows photosynthetic products to be translocated from areas where they are produced to areas where they are in demand, for example to growing axial polyps (Fang et al. 1989) or regenerating edges, where zooxanthellae numbers may be low. The present results suggest that translocation may become more difficult with increasing lesion size as energy reserves are depleted (Rinkevich 1996). If lesions are too large they will not heal through lateral encroachment over the damaged area (Done 1987). The peripheral edge may gradually cease to respond as a unit because of physical constraints preventing the establishment of a coordinated translocation gradient. Establishing a multi-directional gradient may be more limiting than the establishment of a unidirectional response.

Acknowledgements. Many thanks to Sandra van Woesik for research assistance, Masashi Yamaguchi, Yossi Loya and 3 anonymous reviewers for comments on the manuscript, and the Japanese Ministry of Education for funding the study with Grant No. 07740601 in 1995.

\section{LITERATURE CITED}

Bak RPM, Brouns JJWM, Heys FML (1977) Regeneration and aspects of spatial competition in the scleractinian corals Agaricia agaricites and Montastrea annularis. Proc 3rd Int Coral Reef Symp 1:143-149

Bak RPM, Steward-van Es Y (1980) Regeneration of superficial damage in the scleractinian corals Agaricia agaricites f. Purpurea and Porites astreoides. Bull Mar Sci 30(4):883887

Barnard LA, MacIntyre IG, Pierce JW (1974) Possible envi- ronmental index in tropical reef corals. Nature 252: $219-220$

Barnes DJ, Lough JM (1993) On the nature and causes of density banding in massive coral skeletons. J Exp Mar Biol Ecol 167:91-108

Birkeland C (1989) The faustian traits of the crown-of-thorns starfish. Am Sci 77:154-163

Boto K, Isdale P (1985) Fluorescent bands in massive corals result from terrestrial fulvic acid inputs to nearshore zone. Nature 315:396-397

Brown BE, Le Tissier MDA, Scoffin TP, Tudhope AW (1990) Evaluation of the environmental impact of dredging on intertidal coral reefs at Ko Phuket, Thailand, using ecological and physiogical parameters. Mar Ecol Prog Ser 65: $273-281$

Brown BE, Tudhope AW, Le Tissier MDA, Scoffin TP (1991) A novel mechanism for iron incorporation into coral skeletons. Coral Reefs 10:211-215

Buddemeier RW, Kinzie RA (1976) Coral growth. Oceanogr Mar Biol Annu Rev 14:183-225

Cameron AM, Endean R (1985) Do long-lived species structure coral reef ecosystems? Proc 5th Int Coral Reef Symp 6: $211-216$

Davies PJ (1983) Reef growth. In: Barnes DJ (ed) Perspectives on coral reefs. Australian Institute of Marine Science Publ, Canberra, p 69-106

Done TJ (1987) Simulation of the effects of Acanthaster planci on the population structure of massive corals in the genus Porites: evidence of population resilience? Coral Reefs 6: $75-90$

Endean R, Cameron AM, De Vantier LM (1988) Acanthaster planci predation on massive corals: the myth of rapid recovery of devastated reefs. Proc 6th Int Coral Reef Symp $2: 143-148$

Fang LS, Chen YWJ, Chen CS (1989) Why does the white tip of stony coral grow so fast without zooxanthellae? Mar Biol 103:359-363

Fishelson L (1973) Ecological and biological phenomena influencing coral-species composition on the reef tables at Eilat (Gulf of Aqaba, Red Sea). Mar Biol 19:183-196

Gagan MK, Chivas AR, Isdale PJ (1994) High-resolution isotope records from corals using ocean temperature and mass-spawning chronometers. Earth Planet Sci Lett 121: $549-558$

Gladfelter EH (1983) Circulation of fluids in the gastrovascular system of the reef coral Acropora cervicornis. Biol Bull (Woods Hole) 165:619-636

Hopley D (1982) The geomorphology of the Great Barrier Reef: quaternary development of coral reefs. John WileyInterscience, New York

Isdale P (1984) Fluorescent bands in massive corals record centuries of coastal rainfall. Nature 310:578-579

Jokiel PL, Hunter CL, Taguchi S, Watari L (1993) Ecological impact of a freshwater 'reef kill' in Kaneohe Bay, Oahu, Hawaii. Coral Reefs 12:177-184

Kawaguti S (1937) On the physiology of reet corals. III. Regeneration and phototropism in reef corals. Palao Trop Biol Stn Stud 1(2):209-216

Keesing JK, Bradbury RH, De Vantier LM, Riddle MJ, De'ath $G$ (1992) Geological evidence for recurring outbreaks of crown-of-thorns starfish: a reassessment from an ecological perspective Coral Reefs 11:79-85

Lester RT, Bak RPM (1985) Effects of environment on regeneration rate of tissue lesions in the reef coral Montastrea annularis (Scleractinia). Mar Ecol Prog Ser 24:183-185

Loya Y (1976) Skeletal regeneration in a Red Sea scleractinian coral population. Nature 261:490-491 
McCullock MT, Gagan MK, Mortimer GE, Chivas AR, Isdale PJ (1994) A high-resolution $\mathrm{Sr} / \mathrm{Ca}$ and $\delta^{18} \mathrm{O}$ coral record from the Great Barrier Reef, Australia, and the 1982-1983 EI Niño. Geochim Cosmochim Acta 58:2727-2754

Meesters EH, Bak RPM (1993) Effects of coral bleaching on tissue regeneration potential and colony survival. Mar Ecol Prog Se: 96:189-198

Meesters EH, Bos A, Gast GJ (1992) Effects of sedimentation and lesion position on coral tissue regeneration. Proc 7 th Int Coral Reef Symp 2:671-678

Meesters EH, Noordeloos M, Bak RPM (1994) Damage and regeneration: links to growth in the reef-building coral Montastrea annularis. Mar Ecol Prog Ser 112:119-128

Meesters EH, Wesseling I, Bak RPM (1996) Partial mortality in three species of reef-building corals and the relation with colony mortality. Bull Mar Sci 58(3):838-852

Oren U, Benayahu Y, Loya Y (1997) The effect of lesion size and shape on regeneration of the Red-Sea coral Favia favus. Mar Ecol Prog Ser 146:101-107

Rinkevich B (1996) Do reproduction and regeneration in dam-

Editorial responsibility: Otto Kinne (Editor)

Oldendorf/Luhe, Germany aged corals compete for energy allocation? Mar Ecol Prog Ser 143:297-302

Ruesink JL (1997) Coral injury and recovery: matrix models link process to pattern. $J$ Exp Mar Biol Ecol 210:187-208

Sokal RR, Rohlf FJ (1995) Biometry. WH Freeman and Company, New York

Stephenson TA, Stephenson A (1933) Growth and asexual reproduction in corals. Great Barrier Reef Expedition 1928-29 Scientific Reports, British Museum, London, 3(7) $167-217$

Taylor DL (1977) Intra-co.onial transport of organic compounds and calcium in some Atlantic reef corals. Proc $3 \mathrm{rd}$ Int Coral Reef Symp 1:431-436

Thompson DW (1917) On growth and form. Cambridge University Press, Cambridge

Veron JEN (1995) Corals in space and time: the biogeography and evolution of the scleractinia. University of New South Wales Press, Sydney

Woodroffe C. McLean R (1990) Microatolls and recent sea level change on coral atolls. Nature 344:531-534

Submitted: July 31. 1997: Accepted: January 7. 1998 Proofs received from author(s): March 13, 1998 